\title{
PENGARUH LATIHAN LARI ANGKAT PAHA TERHADAP PRESTASI LARI SPRINT 100 METER PADA SISWA PUTRA KELAS VIII SMP NEGERI 3 WOHA KABUPATEN BIMA
}

\author{
Salahudin ${ }^{1 *}, \operatorname{Irfan}^{2}$ \\ ${ }^{1}$ Program Studi Pendidikan Jasmani Kessehatan dan Rekreasi, STKIP Taman Siswa Bima, Bima, Indonesia \\ ${ }^{2}$ Program Studi Pendidikan Jasmani Kessehatan dan Rekreasi, STKIP Taman Siswa Bima, Bima, Indonesia \\ *salahudin3009@gmail.com
}

(Received: June 2020 / Revised: July 2020 / Accepted: July 2020)

\begin{abstract}
ABSTRAK: Masalah yang ingin dipecahkan dalam penelitian ini adalah untuk mengetahui apakah ada pengaruh latihan lari angkat paha terhadap prestasi lari sprint 100 meter pada siswa SMP Negeri 3 Woha Kabupaten Bima. Dalam penelitian ini menggunakan metode eksperimen dan Teknik pengumpulan data dalam penelitian ini menggunakan metode dokumentasi dan tes keterampilan. Teknik analisis data menggunaka rumus t-test. Penelitian ini menghasilkan nilai t-hitung lebih besar dari angka penolakan hipotesis nol $(2,868<2,074)$. Hal ini berarti nilai t hitung tersebut signifikan, dengan demikian hipotesis nol ditolak dan alternatif diterima. Kesimpulan dari penelitian ini adalah terdapat pengaruh latihan lari angkat paha terhadap prestasi lari sprint 100 meter pada siswa putra SMP Negeri 3 Woha Kabupaten Bima

KATA KUNCI: Pengaruh Latihan, Lari Angkat Paha, Prestasi Lari Sprint 100 Meter.

ABSTRACTS: The problem to be solved in this study is to find out whether there is an effect of the practice of thigh-running exercises on the achievement of 100-meter sprints running at students of State Middle School 3 Woha Bima Regency. In this study using the experimental method and data collection techniques in this study using the method of documentation and test skills. Data analysis techniques using the $t$-test formula. This study resulted in a $t$-test value greater than the null hypothesis rejection rate $(2.868<2.074)$. This means that the $t$ value is significant, thus the null hypothesis is rejected and alternatives are accepted. The conclusion of this study is that there is an effect of the practice of thigh-running exercises on the 100 meter sprint running achievement of male students of SMP Negeri 3 Woha, Bima Regency

\section{PENDAHULUAN}

Latihan lari Angkat paha merupakan sebuah latihan mengangkat kaki bagian atas setinggi $90 \%$ dengan keadaan rileks dan kaki kebanyakan angkat kedepan dari pada kebelakang (A.J. Soesatyo, 1975:26). Ada beberapa teknik latihan lari angkat paha seperti: berdiri tegak kedua lengan bebas, disamping badan sambil berjalan, dengan cara angkat tumit kaki kanan, lutut kedepan lurus dengan menekan tumit kaki kanan kebawah, tumit kaki kiri diangkat dan lutut lurus kedepan. Latihan ini bisa dilakukan bergantian beberapa kali dengan jarak antara $10 \mathrm{~m}-30 \mathrm{~m}$ sampai gerakannya baik dan tambah lam tambah cepat gerakannya, Berlari dengan lutut diangkat tinggi disertai dengan

Page | 9 pelurusan bagian bawah tungkai, Gerakan simulasi ini menyerupai gerakan menyepak ala kuda, gerakan maju dilakukan dengan pelan, tetapi kecepatan dari kedua tungkai menyerupai lari ditempat. Pelaku (atlet/anak) dapat memulai gerakan lari dengan lutut diangkat tidak begitu tinggi. Dalam satu kali irama langkah angkatlah lutut dan luruskan tungkai bagian bawah, dan Menendang Pantat di setiap anda bergerak pelan kedepan, tendangkan tumit kebelakang dan cobalah untuk dapat menyentuh pantat. Latihan ini untuk membantu membentuk gerakan menendang kebelakang badan dan juga memperlonggar otot quadriceps femoris.

Lari sprint $100 \mathrm{~m}$ merupakan salah satu nomor cabang atletik yang membutuhkan unsurunsur kecepatan dan kemampuan daya ledak 
otot tungkai untuk mencapai prestasi maksimal. Adanya hubungan yang positif antara tingkat kondisi fisik dengan pencapaian prestasi tersebut mendorong peneliti membuktikan pengaruh latihan lari angkat paha terhadap prestasi lari sprint $100 \mathrm{~m}$. Lari sprint tidak hanya sekedar lari seperti biasa namun memiliki teknik diantaranya yaitu: langkah selebar atau gerakan kaki atau secepat mungkin, kaki belakang pada saat meninggalkan tanah atau saat mnolak harus benar-benar lurus dan dengan cepat untuk ditekuk secara wajar agar paha lebih mudah diangkat kedepan, gerakan lengan saat diayun secara rileks dan siku ditekuk kira-kira 90 derat, pergelangan tangan dan jari-jari tangan harus rileks setengah menggenggam, pendaratan kaki harus pada ujung telepak kaki sedangkan lutut dalam keadaan agak dingkat, dan otot leher dan rahang tetap rileks, jangan sampai mulutnya ditutup dan kepala harus lurus dengan punggung serta pandangan tetap lurus.

Lari sprint (pendek) adalah semua jenis lari yang menempuh jarak 400m kebawah (tamsir riyadi, 1982:87), ahli lain menyebutkan bahwa lari jarak pendek sebagai salah satu cabang lomba mencakup semua jarak hingga 400m (gerry a. carr, 1997:65). Adapun menurut Aipsyarifuddin (1997:45) menjelaskan bahwa lari 100m adalah lari dimana atlet menempuh jarak dengan maksimal, sepanjang jarak $100 \mathrm{~m}$.

Prestasi olahraga telah terbukti dapat memperkenalkan bahkan dapat mempertinggi derajat suatu Negara yang pada awalnya tidak pernah diperhitungkan oleh Negara-negara lain yang merasa dirinya lebih besar. Hal ini dapat kita buktikan dari beberapa penyelenggara olahraga yang bersifat daerah, nasional, maupun internasional, dimana suatu daerah maupun Negara baru dikenal setelah seorang atlet meraih juara.

Prestasi (Zainal Arifin, 1990) mengatakan bahwa, prestasi adalah kemampuan, keterampilan dan sikap seseorang dalam Page | 10 menyelesaikan suatu hal. Pandangan diatas pada dasarnya memahami prestasi sebagai suatu hal dari sebuah tindakan atau aktifitas. Itu artinya bahwa suatu prestasi tidak akan pernah diraih oleh seseorang jika sekiranya aktifitas itu tidak terjadi sebelumnya. Jelasnya suatu prestasi dimungkinkan terjadi atau ada setelah ada proses belajar dan berlatih setelah sebelumnya dilakukan perencanaan yang baik dan matang. Selanjutnya sebuah prestasi akan mendatangkan hasil yang baik (maksimal) adalah sangat tergantung dari mekanisme pengaturan (manajement) dan aktifitas yang dijalankan. Sejalan dengan pernyataan (Leonard, 1990) dan (Monty, 1996), membina prestasi olehraga seseorang tidak hanya dapat dilakukan dalam suatu malam, melainkan dalam berbagai proses dan tahapan dalam kurun waktu tertentu, sekalipun individu itu memiliki bakat khusus pada bidang olahraga, tanpa latihan yang terarah bakat tersebut akan tetap tinggal sebagai potensi yang terpendam.

Latihan lari interval adalah salah satu sistem yang diselingi interval-interval berupa masa kerja dan istirahat. Interval kerja adalah bagian dari latihan interval yang terdiri dari kerja yang ringan, sedang, maupun yang berat sedangkan interval istirahat adalah bagian dari interval kerja yang terdiri dari istirahat-istirahat yang diberikan antara repetisi latihan. (Sajato: 1988) mengatakan bahwa terdapat beberapa istilah yang dipergunakan dalam penyusun program-program latihan antaralain: Set, Repetisi, Waktu istirahat, Jarak latihan, Frekuensi latihan, dan waktu istirahat antara repetisi dan antara set.

Kecepatan merupakan salah satu unsur latihan fisik yang memegang peran penting untuk menunjang peningkatan prestasi atlet dalam upaya peningkatan prestasi atlet. Namun demikian sering kali para atlet dalam upaya peningkatan kecepatan melakukan bentuk latihan yang lebih ditekankan pada peningkatan kelincahan atau unsur fisik yang lain, sehingga 
tidak memenuhi tujuan latihannya, hal ini disebabkan karena pengertian tentang kecepatan belum dapat dipahami secara benar. Dan dalam pengertian yang lain Kecepatan adalah untuk melakukan gerakan-gerakan yang sejenis secara berurut-urut dalam waktu yang sesingkatsingkatnya, atau kemampuan untuk menempuh jarak tertentu, terutama jarak pendek dalam waktu yang sesingkat-singkatnya.

\section{METODE PENELITIAN}

Metode penelitian yang digunakan dalam penelitian ini adalah metode eksperimen. Metode eksperimen adalah suatu kegiatan untuk meneliti suatu gejala yang dinamakan latihan atau perlakuan. Dasar menggunakan metode eksperimen adalah kegiatan percobaan yang diwakili dengan memberikan perlakuan terhadap subjek dan diakhiri dengan tes untuk menguji kebenarannya.

Ditinjau dari proses pengambilan data, bentuk-bentuk data yang akan didapat serta tujuan maka jenis penelitian tergolong dalam penelitian eksperimental. Menurut (Sumadi Suryabrata) dalam bukunya metode penelitian menyatakan bahwa: "Rancangan penelitian itu dapat di golongkan menjadi empat (4) macam kategori yaitu: Mendapatkan data nama-nama siswa yang akan dijadikan sampel, melakukan pre-test (Tes awal) yaitu lari sprint $100 \mathrm{~m}$ yang menjadi sampel penelitian, melakukan pelatihan lari angkat paha dan sesuai dengan program latihan, dan melakukan post-test lari sprint $100 \mathrm{~m}$.

Dengan demikian maka dalam penelitian ini yang sesuai dengan tujuan serta sifat masalahnya dari kesembilan macam rancangan penelitian di atas tergolong ke poin dua yaitu melakukan pre-test "one group, pre-test, posttest design (Suryabrata 1983: 41), dalam uraian seperti yang dikemukakan oleh Suryabrata "Satu kelompok subyek pertama-tama dilakukan pengukuran (pre-test), lalu dikenakan perlakuan untuk jangka waktu tertentu, kemudian dilakukan pengukuran untuk kedua kalinya (post-test)".

Sehubungan dengan penelitian ini, maka rancangan penelitian menggunakan "One Group Experiment atau yang disebut juga dengan Treatment By Subjects Designs" (Sutrisno Hadi, 1988:153). Penggunaan rancangan penelitian ini, karena diberikan kepada sekelompok subyek yang sama group percobaan sekaligus sebagai group kontrol.

Untuk memperoleh data yang valid dan akurat yang diperlukan oleh peneliti maka dibutuhkan Instrumen-instrumen adalah alat pada waktu penelitian dengan menggunakan suatu metode (Arikunto, 2006:149). Sebagaimana dikemukakan oleh Nurul Zuriah, bahwa ada beberapa hal yang perlu diperhatikan dalam menyusun instrumen penelitian, yaitu masalah dan variabel yang diteliti termasuk indikator variabel, harus jelas spesifik sehingga dapat dengan mudah menetapkan jenis instrumen yang akan digunakan, dan Sumber data atau sumber informasi, baik jumlah maupun keragamannya harus diketahui terlebih dahulu sebagai bahan atau dasar dalam menentukan isi, bahasa, sistematika item dalam instrumen penelitian (Nurul Zuriah, 2006 : 168).

\section{HASIL}

Dari hasil pengujian nilai t-hitung dapat dilaksanakan dengan menggunakan taraf signifikansi $5 \%$ dan sesuai dengan rumus yang dipakai yaitu t-test, Untuk menguji signifikansi nilai dilakukan dengan membandingkan harga thitung $(3,114)$ dengan t-tabel $(2,074)$. Kenyataan ini menunjukkan bahwa t-hitung lebih besar dari angka penolakan hipotesis nol $(3,114<2,074)$. Hal ini berarti nilai t-hitung tersebut signifikan.Dengan demikian hipotesis nol ditolak dan alternatif diterima.

Jadi dari hasil penelitian yang diperoleh $\mathrm{t}$ hitung jauh lebih besar dari pada t-tabel. Ini 
mengemukakan bahwa ( $\mathrm{Ha}$ ) diterima dan ( $\mathrm{Ho})$ ditolak.

Tabel 1. Deskripsi Data Pre-Test Dan Post-Test

\begin{tabular}{ccccccc}
\hline $\begin{array}{c}\text { Subjek } \\
\text { (N) }\end{array}$ & (X1) & (X2) & Md & D & D & $\mathbf{d}^{2}$ \\
\hline 23 & 2682 & 3283 & -26.2 & -601 & -24.6 & $35.528,68$ \\
\hline
\end{tabular}

Berdasarkan hasil analisis diatas dapat disimpulkan bahwa," Ada pengaruh latihan lari angkat paha terhadap prestasi lari sprint $100 \mathrm{~m}$ pada siswa putra SMP Negeri 3 Woha.

\section{PEMBAHASAN}

Dalam penelitian ini ada beberapa yang harus dibahas seperti cara pengambilan datanya, dalam pengambilan data peneliti menggunakan dua metode yaitu metode perlakuan, metode perlakuan yang dilakukan oleh peneliti yaitu tes lari sprint $100 \mathrm{~m}$ sebelum melakukan latihan dan sesudah melakukan latihan yaitu latihan lari angkat paha. Metode dokumentasi mencatat semua hasil dalam penelitian kedalam sebuah buku. Didalam metode penelitian ini juga menggunakan metode pengumpulan data dengan menggunakan metode "Proportional Random Smpling" karena jumlah subjeknya diatas 100 orang. Sedangkan dalam penganalisis data menggunakan analisis statistik dengan menggunakan rumus $t$-test.

Lari cepat atau sprint adalah semua perlombaan lari dimana peserta berlari dengan kecepatan maksimal sepanjang jarak yang harus ditempuh, sampai dengan jarak 400m masih dapat digolongkan dalam lari cepat. Menurut Muhajir (2004) sprint atau lari cepat yaitu, perlombaan lari dimana peserta berlari dengan kecepatan penuh yang menempuh jarak $100 \mathrm{~m}$, $200 \mathrm{~m}$, dan $400 \mathrm{~m}$. Kebutuhan yang relatif penting untuk lari sprint sangat beragam bergantung pada kategori usia. Sprint yang baik membutuhkan reaksi yang cepat, akselerasi yang baik, dan jenis lari yang efisien. Sprinter juga harus mengembangkan start sprint yang baik dan mempertahankan kecepatan puncak selama mungkin.Dalam lari sprint harus memperhatiakn Page | 12 sistem energi yang digunakan karena atlet mengunakan persediaan energi yang tersimpan atau kapasitas an-aerobik (Khomsin, 2011).

Dari hasil analisis data yang ada bahwa ttabel lebih kecil dari pada t-hitung (2.074 > 3,114). Meningat dari hasil tersebu bahwa ada pengaaruh latihan lari angkat paha terhadap prestasi lari sprint $100 \mathrm{~m}$ pada siswa putra SMP Negeri 3 WohaKabupaten Bima.

Mengingat bahwa yang digunakan dalam penelitian ini adalah teknik analisa data statistik, maka hipotesa kerja tersebut diubah menjadi hipotesis Nihil (Ho): "Ada pengaruh latihan lari angkat paha terhadap prestasi lari sprint $100 \mathrm{~m}$ pada siswa putra SMP Negeri 3 WohaKabupaten Bima" Sesuai dengan kenyataan dari hasil analisis data diatas bahwa rendahnya prestasi lari sprint yang dialami oleh sebagian siswa bukan hanya disebabkan lari itu melelehkan tetapi juga sebagian disebabkan oleh beberapa faktor, seperti: faktor latihan, kekuatan, kelenturan, mental, kemauan, dukungan serta kesehatan dan yang paling pentig lagi adalah tehnik dan taktik.

Dengan demikian sangat perlu adanya usaha guna membantu para siswa kita dalam meningkatkan prestasi mereka dalam cabang olahgara terutama cabang atletik, karena atletik merupakan induk dari semua cabang olahraga. Salah satu bentuk yang kita berikan adalah latihan secara sistematis dan berkelanjutan sesuai dengan program latihan tertentu.Dismping itu juga bagi guru pendidikan olahraga disekolahsekolah agar bisa membimbing dan melatih anakanak didiknya agar mencapai prestasi yang lebih tinggi.

\section{SIMPULAN DAN REKOMENDASI}

Kesimpulan yang dapat ditarik dalam penelitian ini adalah adanya pengaruh latihan lari angkat paha terhadap prestasi lari sprint $100 \mathrm{~m}$ pada siswa putra SMP Negeri 3 Woha Kabupaten Bima. 


\section{UCAPAN TERIMAKASIH}

Penelitian ini tentu berbagai pihak telah membantu dalam peneliti ini untuk penyusunan dai awal sampai pada kelengkapan data pada saat melaksanakan penelitian di lapangan.

a. Ucapan terima kasih kepada Bappeda yang telah memberikan rekomendasi ke pada peneliti untuk melakukan penelitian di wilayah Kabupaten Bima.

b. Ucapan terimakasih kepada pihak sekolah yang telah banyak memberikan kesempatan kepada peneliti untuk melaksanakan penelitian di SMP Negeri 3 Woha Kabupaten Bima.

c. Ucapan terimakasih juga pada semua pihak yang telah banyak membantu terlaksananya penelitian mulai dari awal sampai akhir penelitian.

\section{REFERENSI}

Arikunto, Suharsimi. 2010. Prosedur Penelitian. Jakarta: PT. Rineka Cipta.

Depdikbud, 1985, Atletik, Sejarah, Reknik dan Metodik, Jakarta

Depdikbud, 1979, Atletik (Latihan dan Penyelenggaraan Perlombaan), Jakarta

Endurance Athletes?". Journal Of Sports Physiology And Performance. Vol 5. 2010: 276-291

J.M.Ballesteros(spanyol), pedoman latihan dasar atletik,

Junaidin, 2008. pengaruh latihan 25 meter terhadap prestasi lompat jauh. penulis karya ilmiah IKIP mataram

Lalu Hulfian, 2013. Statistik dikjas, Mataram

Satriya, Sidik japar Dikdik dan Imanudin Imam, 2007, latihan meteologi olahraga, yayasan penerbit: fakultas pendidikan olahraga dan kesehatan kepel universitas pendidikan indonesia bandung.

Suharjo, S, 1988, Evaluasi Hasil Belajar dalam bidang Olahraga.
Syaiful Musaddat, 2006, Aplikasi bahasa Indonesia.

Tamsir Riyadi, 1992, Petunjuk Pengajaran Atletik. Tim, 2011.

Khomsin. 2011. Atletik 1. Semarang: UPT UNNES Press.

Rahman, Abdul, 2015, Journal of Sport Sciences and Fitness 4 (1)

Sutrisno Hadi. 2004. MetedologiReasarch. Yogyakarta : Andi Offse 